\title{
Identification of Risk Factors Associated with Fatal Intersection Crashes and Assessment of the In-Service Safety Performance of Signalized Intersections and Roundabouts in Abu Dhabi
}

\author{
Dina Mustafa Mohammad Awadalla ${ }^{1}$ and Francisco Daniel Benicio de Albuquerque ${ }^{2, *}$ \\ 1 Graduate Research Assistant, Civil \& Environmental Engineering Department, United Arab Emirates \\ University, Al Ain P.O. Box 15551, United Arab Emirates; 201770149@uaeu.ac.ae \\ 2 Faculty of Transportation Engineering, Civil \& Environmental Engineering Department, United Arab \\ Emirates University, Al Ain P.O. Box 15551, United Arab Emirates \\ * Correspondence: daniel@uaeu.ac.ae; Tel.: +971-03-713-5172
}

check for updates

Citation: Awadalla, D.M.M.; de Albuquerque, F.D.B. Identification of Risk Factors Associated with Fatal Intersection Crashes and Assessment of the In-Service Safety Performance of Signalized Intersections and Roundabouts in Abu Dhabi. Safety 2021, 7, 69. https://doi.org/ 10.3390/safety7040069

Academic Editor: Raphael Grzebieta

Received: 29 July 2021

Accepted: 28 September 2021

Published: 13 October 2021

Publisher's Note: MDPI stays neutral with regard to jurisdictional claims in published maps and institutional affiliations.

Copyright: (c) 2021 by the authors. Licensee MDPI, Basel, Switzerland. This article is an open access article distributed under the terms and conditions of the Creative Commons Attribution (CC BY) license (https:/ / creativecommons.org/licenses/by/ $4.0 /)$.

\begin{abstract}
Several research studies conducted in North America and Europe have consistently shown that converting signalized intersections into roundabouts leads to safety benefits. These studies have led North American and European transportation agencies to convert hundreds of signalized intersections into roundabouts over the last few decades. Meanwhile, the Emirate of Abu Dhabi, the largest emirate in the United Arab Emirates (UAE), has replaced many of its long-standing roundabouts with signalized intersections (i.e., controlled by traffic lights) despite the fact that no UAE-based scientific study comparing the safety performance of these two intersection types can be found in the literature. Hence, the objectives of this paper are to (i) identify factors that significantly contribute to fatal intersection-related crashes and (ii) assess the in-service safety performance of signalized intersections and roundabouts. It is anticipated that the findings from this research will provide road designers and decision-makers with much needed scientific guidance on which factors contribute to fatal intersection crashes as well as on whether converting existing roundabouts into signalized intersections improves public safety or not in Abu Dhabi. The findings from this research should also benefit neighboring Gulf Cooperation Council (GCC) countries considering their similarities in road design, traffic characteristics, and driving culture.
\end{abstract}

Keywords: traffic safety; intersection crashes; injuries; logistic regression; Abu Dhabi

\section{Introduction}

\subsection{Background}

Traffic-related injuries and deaths have been a significant public health problem not only in the United Arab Emirates (UAE) [1-3], but also in other Gulf Cooperation Council (GCC) countries (i.e., Bahrain, Kuwait, Oman, Qatar, and Saudi Arabia) [4-9]. More specifically, intersection crashes account for a disproportional number of trafficrelated injuries and deaths in Abu Dhabi [10]. In fact, intersection crashes have accounted for a significant portion of all road-related crashes and severe injuries worldwide. For instance, intersection crashes have accounted for one-quarter and one-half of all trafficrelated fatalities and injuries, respectively, in the United States (US) [11]. Thus, considering that the World Health Organization (WHO) has defined road crashes as a serious public health problem [12], and given the significant number of traffic-related crashes and deaths occurring at intersections, it is imperative that both the number and (most importantly) the severity of crashes occurring at intersections be reduced if road safety is to be improved.

In Abu Dhabi city, running-red-light crashes alone have been found to account for almost one-fifth of all traffic-related fatalities. Eighty-five percent of these crashes involved right-angle impacts, while the number of injuries and vehicles involved in these crashes were found to be 27 and 32\%, respectively, higher as compared to those from all crash 
types combined [10]. Roundabouts may be a design alternative with the potential to improve safety in Abu Dhabi intersections. Roundabouts may improve safety by lowering traveling speeds due to the presence of the center island and curved approaches. In addition, circular movements and angled entry trajectories decrease the chance of more severe impact conditions such as those involved in right-angle collisions [13-60].

Indeed, scientific research has found that the adoption of roundabouts should be favored over signalized intersections (i.e., controlled by traffic lights) if safety is to be improved. However, the Emirate of Abu Dhabi has so far converted several of its longstanding roundabouts into signalized intersections $[61,62]$. This is puzzling, as a significant amount of research has shown that this move may pose a mobility safety threat to the motoring public in the UAE. For example, research conducted in the 2000s reported a meta-analysis of several studies [13-50] conducted between 1975 and 1997 outside the US (see Table 1) [63]. These studies used two different study designs: before-after (most of them) and cross-sectional. Unfortunately, many of these studies did not control for the regression-to-the-mean (RTM) phenomenon [64]. The findings from this comprehensive, meta-analysis-based study revealed that roundabouts are associated with a 30 to $50 \%$ reduction in the number of injury accidents, while fatal accidents are reduced by 50 to $70 \%$.

Table 1. List of Studies [13-50] Included in the Meta-Analysis-Based Research Conducted by Elvik (2003) [63].

\begin{tabular}{|c|c|c|c|c|c|}
\hline Year & Authors & Country & Design & $\begin{array}{l}\text { Controls for } \\
\text { RTM }\end{array}$ & $\begin{array}{c}\text { Number of } \\
\text { Estimates of Effect }\end{array}$ \\
\hline 1975 & Lalani & Great Britain & Before-after & No & 2 \\
\hline 1977 & Green & Great Britain & Before-after & No & 8 \\
\hline 1981 & Lahrmann & Denmark & Both designs & No & 4 \\
\hline 1983 & Cedersund & Sweden & Cross-section & Not relevant & 20 \\
\hline 1983 & Senneset & Norway & Before-after & No & 1 \\
\hline 1985 & Brüde and Larsson & Sweden & Before-after & Yes & 1 \\
\hline 1985 & Johannessen & Norway & Cross-section & Not relevant & 2 \\
\hline 1988 & $\begin{array}{l}\text { Hall and } \\
\text { McDonald }\end{array}$ & Great Britain & Cross-section & Not relevant & 4 \\
\hline 1988 & Nygaard & Norway & Before-after & No & 1 \\
\hline 1990 & Giaever & Norway & Cross-section & Not relevant & 3 \\
\hline 1990 & Van Minnen & Netherlands & Before-after & No & 4 \\
\hline 1991 & Jørgensen & Denmark & Before-after & No & 3 \\
\hline 1992 & Brüde and Larsson & Sweden & Cross-section & Not relevant & 12 \\
\hline 1992 & Dagersten & Switzerland & Before-after & No & 2 \\
\hline 1992 & Holzwarth & Germany & Before-after & No & 2 \\
\hline 1992 & Hydén et al. & Sweden & Before-after & No & 8 \\
\hline 1992 & Johannessen & Denmark & Before-after & No & 2 \\
\hline 1992 & Kristiansen & Norway & Before-after & No & 4 \\
\hline 1992 & Schnüll et al. & Germany & Before-after & No & 2 \\
\hline 1992 & Værø & Denmark & Before-after & No & 2 \\
\hline 1993 & Brilon et al. & Germany & Before-after & No & 2 \\
\hline 1993 & $\begin{array}{l}\text { Schoon and Van } \\
\text { Minnen }\end{array}$ & Netherlands & Before-after & No & 9 \\
\hline 1994 & Voss & Germany & Cross-section & Not relevant & 4 \\
\hline 1994 & Jørgensen & Denmark & Before-after & Yes & 1 \\
\hline 1994 & Seim & Norway & Before-after & No & 3 \\
\hline 1994 & $\begin{array}{l}\text { Huber and } \\
\text { Bühlmann }\end{array}$ & Switzerland & Before-after & No & 2 \\
\hline 1995 & Oslo Veivesen & Norway & Before-after & No & 1 \\
\hline 1996 & Odberg & Norway & Before-after & Yes & 2 \\
\hline 1997 & Giaever & Norway & Before-after & No & 2 \\
\hline
\end{tabular}


More recently, a meta-analysis study investigated the road safety effects of converting junctions into roundabouts [65]. The objective of this study was to update the meta-analysis study conducted in the 2000s [63], as the data used in this older study was not only outdated, but it also focused on non-US studies. A total of 44 studies (i.e., the 33 studies [13-50] shown in Table 1 plus the 11 studies [51-60] shown in Table 2) were included in this meta-analysis-based research, including studies conducted in Norway, Denmark, Great Britain, Sweden, Germany, Switzerland, the Netherlands, Belgium, Australia, and the US. These studies were conducted between 1975 and 2014. Based on a total of 154 estimates of effect, this more recent meta-analysis research [65] showed that converting junctions into roundabouts was associated with a reduction in fatal accidents of about $65 \%$ and a reduction in injury accidents of about $40 \%$. Based on these results, this comprehensive research concluded that roundabouts are very effective in reducing traffic fatalities. Other recent research has confirmed findings from this meta-analysis study [66].

Table 2. List of Studies [13-60] Included in the Meta-Analysis-Based Research Conducted by Elvik (2017) [65].

\begin{tabular}{ccclcc}
\hline Year & Authors & Country & Design & $\begin{array}{c}\text { Controls for } \\
\text { RTM }\end{array}$ & $\begin{array}{c}\text { Number of } \\
\text { Estimates of Effect }\end{array}$ \\
\hline 1990 & Corben et al. & Australia & Before-after & No & 1 \\
\hline 1990 & Tudge & Australia & Before-after & No & 2 \\
\hline 1995 & $\begin{array}{c}\text { Bureau of Transport } \\
\text { and Communications } \\
\text { Economics }\end{array}$ & Australia & Before-after & No & 2 \\
\hline 1996 & Flannery and Datta & United States & Before-after & Yes & 2 \\
\hline 1998 & Flannery et al. & United States & Before-after & No & 2 \\
\hline 1998 & Mountain et al. & Great Britain & Before-after & Yes & 2 \\
\hline 2001 & $\begin{array}{c}\text { Newstead and } \\
\text { Corben }\end{array}$ & Australia & Before-after & Yes & 1 \\
\hline 2001 & Persaud et al. & United States & Before-after & Yes & 7 \\
\hline 2007 & $\begin{array}{c}\text { Brabander and } \\
\text { Vereeck }\end{array}$ & Belgium & Before-after & Yes & 4 \\
\hline 2008 & Meuleners et al. & Australia & Before-after & No & 2 \\
\hline 2009 & Schelling and & Denmark & Before-after & Yes & 1 \\
\hline 2013 & Gross et al. & United States & Before-after & Yes & 4 \\
\hline 2013 & Underlien Jensen & Denmark & Before-after & Yes & 4 \\
\hline 2014 & De Pauw et al. & Belgium & Before-after & Yes & 2 \\
\hline 2014 & Hu et al. & United States & Before-after & No & 4 \\
\hline
\end{tabular}

Even though there has been a significant amount of studies conducted at different points in time and spread throughout several different countries and continents, assessing the safety performance of roundabouts versus signalized intersections in the Emirate of Abu Dhabi is still a relevant research topic, since (i) there has been no scientific evaluation of the in-service safety performance of roundabouts and signalized intersections in the UAE, and (ii) traffic characteristics, vehicle fleet, and driving behavior in the UAE may differ from those in the countries listed in Tables 1 and 2. For example, a recent study conducted using Abu Dhabi crash data found that half of the road crashes were caused by reckless behavior and that Emirati drivers were very overrepresented as the driver at fault in fatal crashes [67]. One of the practices classified as reckless in this study was "no yielding" when yielding was warranted, such as when vehicles are entering roundabouts. Another recent Abu Dhabi study found that the 85th percentile operating speeds from a sample of 18 roundabouts in Abu Dhabi were found to be higher than the design speeds and that motorists perceive roundabouts as unsafe [68]. As such, given the reckless driving behavior tendencies present among Abu Dhabi motorists and the fact that motorists traveling through roundabouts may have more control over factors such as yielding, driving speeds, and gap acceptance as opposed to traveling through signalized intersections, roundabout safety in Abu Dhabi 
may be negatively affected. This potentially reduced roundabout safety could then make roundabouts in Abu Dhabi not as safe as those in North American and European countries.

Thus, there is a need for an evaluation of the in-service safety performance of roundabouts and signalized intersections in the Emirate of Abu Dhabi, especially given that several of its long-standing roundabouts have been (and may continue to be) replaced with signalized intersections.

\subsection{Research Objectives}

This research aims at answering the following questions:

(i) Which crash-, road-, traffic-, intersection-, vehicle-, and driver-related characteristics significantly contribute to more fatal signalized intersection- and roundabout-related crashes?

(ii) Which intersection type presents a higher likelihood for fatal crashes to occur?

\section{Methods}

\subsection{Data Collection and Description}

A multi-year crash database, provided by the Abu Dhabi Traffic Police, was used to study signalized intersection and roundabout injury crashes between 2012 and 2017 in the Emirate of Abu Dhabi, part of the UAE. The Emirate of Abu Dhabi is the largest of the UAE's seven emirates, occupying about $85 \%$ of the country's landmass. Only injury crashes contained location information and, therefore, it was not possible to identify intersection type for non-injury data. In addition, non-injury data did not contain detailed crash descriptions or crash diagrams. As a result, non-injury data was not included in the study. The Abu Dhabi Traffic Police classifies injury data as minor, moderate, severe, and fatal. Deaths occurring up to 30 days after road crashes are included in the fatal injury data. Intersection crashes were retrieved using keyword (i.e., roundabout, signal, and intersection) search within the crash description and location fields. A total of 2147 intersection injury crashes were identified. Crash descriptions and diagrams of these crashes were manually reviewed in order to ensure that crashes occurred within intersection boundaries. This exercise led to the exclusion of 139 crashes (i.e., since they had actually not occurred within an intersection), resulting in a total of 2008 crashes (i.e., 794 roundabout and 1214 signalized intersection crashes). There was no field in the databases for information on the sequence of events, rollover outcome, and intersection type. Thus, all crash descriptions and diagrams had to be manually reviewed to identify intersection type, sequence of crash events, and rollover occurrence outcome. Figure 1 shows examples of crash descriptions and diagrams for some of the studied intersection cases. Table 3 shows all variables included in the study. All crash locations were reviewed on Google Earth in order to collect data on intersection features: roundabout island diameter, number of lanes inside the roundabout, signalized intersection area, presence of left or right turn lanes, curvature of the roundabout entry approach, median width, width of entry approach, presence of access points on the upstream approach, number of intersection approach lanes, crosswalk presence, distance between crosswalk and the roundabout yielding line, presence and length of separate left-turn lanes, presence and length of separate right-turn lanes, number of left and right turn lanes, and number of through lanes (i.e., at signalized intersections). 


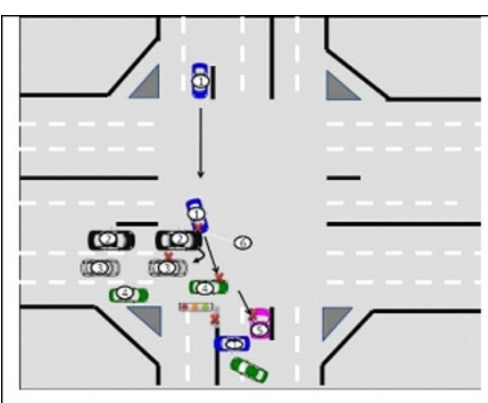

Blue vehicle was traveling southbound when it ran the red light. Blue vehicle then hit black, gray, and green vehicles traveling eastbound as well as a signal post and pink vehicle traveling northbound.

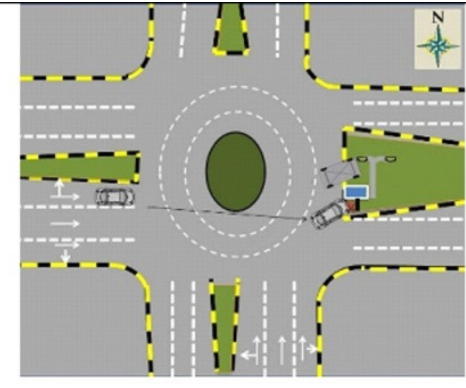

Vehicle was traveling eastbound when it got out of control and hit the curb, sign, and light pole in the median, where it rolled over.

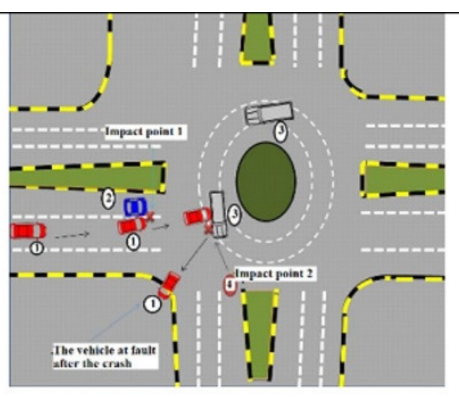

Red vehicle was traveling eastbound recklessly when it side-swiped blue vehicle and hit a truck inside roundabout.

Afterwards, red vehicle hit the curb.

Figure 1. Crash Descriptions and Diagrams.

Table 3. Intersection Crash Data Summary.

\begin{tabular}{|c|c|c|c|}
\hline Variable & Categories & Frequency & $\%$ \\
\hline \multirow{3}{*}{ Presence of Access Points } & No & 421 & 21.0 \\
\hline & Yes & 1441 & 71.8 \\
\hline & Unknown & 146 & 7.3 \\
\hline \multirow{2}{*}{ Number of Crash Events } & One & 1253 & 62.4 \\
\hline & Multiple & 755 & 37.6 \\
\hline \multirow{2}{*}{$\begin{array}{l}\text { Number of Vehicles } \\
\text { Involved }\end{array}$} & One & 732 & 36.5 \\
\hline & Multiple & 1276 & 63.5 \\
\hline \multirow{3}{*}{$\begin{array}{l}\text { Number of Intersection } \\
\text { Approach Lanes }\end{array}$} & 3 or less & 841 & 41.9 \\
\hline & 4 or more & 1019 & 50.7 \\
\hline & Unknown & 148 & 7.4 \\
\hline \multirow{2}{*}{$\begin{array}{c}\text { Number of Intersection } \\
\text { Arms }\end{array}$} & 3 or less & 517 & 25.7 \\
\hline & 4 or more & 1491 & 74.3 \\
\hline \multirow{2}{*}{ Driver Age } & Continuous & 1989 & 99.1 \\
\hline & Unknown & 19 & 0.9 \\
\hline \multirow{3}{*}{ Driver Nationality } & Emirati & 595 & 29.6 \\
\hline & Others & 1405 & 70.0 \\
\hline & Unknown & 8 & 0.4 \\
\hline \multirow{3}{*}{ Driver Gender } & Male & 1709 & 85.1 \\
\hline & Female & 291 & 14.5 \\
\hline & Unknown & 8 & 0.4 \\
\hline \multirow{4}{*}{ Crash Type } & Angled & 877 & 43.7 \\
\hline & Run-of-Road & 512 & 25.5 \\
\hline & Rear-End/Head-On & 387 & 19.3 \\
\hline & Others & 232 & 11.6 \\
\hline \multirow{3}{*}{$\begin{array}{c}\text { Distance Between } \\
\text { Signalized Intersections }\end{array}$} & $\leq 500 \mathrm{~km}$ & 378 & 31.1 \\
\hline & $>500 \mathrm{~km}$ & 762 & 62.8 \\
\hline & No Intersection/Unknown & 74 & 6.1 \\
\hline Distance Between & $\leq 1 \mathrm{~km}$ & 281 & 35.4 \\
\hline \multirow{2}{*}{$\begin{array}{c}\text { Roundabout and Nearest } \\
\text { Intersection }\end{array}$} & $>1 \mathrm{~km}$ & 300 & 37.8 \\
\hline & No Intersection/Unknown & 213 & 26.8 \\
\hline
\end{tabular}


Table 3. Cont.

\begin{tabular}{|c|c|c|c|}
\hline Variable & Categories & Frequency & $\%$ \\
\hline \multirow{2}{*}{ Land Use } & Urban & 1835 & 91.4 \\
\hline & Rural & 173 & 8.6 \\
\hline \multirow{4}{*}{$\begin{array}{l}\text { Presence of Separate } \\
\text { Left-Turn Lane }\end{array}$} & No Lanes & 945 & 51.7 \\
\hline & Single Lane & 584 & 47.2 \\
\hline & Multiple Lanes & 450 & 1.0 \\
\hline & Unknown & 29 & 1.0 \\
\hline \multirow{2}{*}{ Length of Left-Turn Lane } & Continuous & 1973 & 98.3 \\
\hline & Unknown & 35 & 1.7 \\
\hline \multirow{2}{*}{ Road Light Condition } & Good & 1958 & 97.5 \\
\hline & Poor or No Light & 50 & 2.5 \\
\hline \multirow{4}{*}{ Median Width } & $\leq 5 \mathrm{~m}$ & 441 & 22.0 \\
\hline & 5 to $10 \mathrm{~m}$ & 886 & 44.1 \\
\hline & $>10$ & 502 & 25.0 \\
\hline & Unknown & 179 & 8.9 \\
\hline \multirow{4}{*}{ Object Struck } & Vehicle & 1237 & 61.6 \\
\hline & Roadside Hazard & 513 & 25.5 \\
\hline & Nothing & 59 & 2.9 \\
\hline & Others & 199 & 9.9 \\
\hline \multirow{3}{*}{ Driver Physical Condition } & Impaired & 107 & 5.3 \\
\hline & Not Impaired & 1128 & 56.2 \\
\hline & Unknown & 773 & 38.5 \\
\hline \multirow{3}{*}{$\begin{array}{c}\text { Presence of Pedestrian } \\
\text { Crosswalk }\end{array}$} & Yes & 1376 & 68.5 \\
\hline & No & 579 & 28.8 \\
\hline & Unknown & 53 & 2.6 \\
\hline \multirow{3}{*}{ Weather } & Not Adverse & 1953 & 97.3 \\
\hline & Adverse & 44 & 2.2 \\
\hline & Unknown & 11 & 0.5 \\
\hline \multirow{2}{*}{ Posted Speed Limit (kph) } & $\leq 60$ & 1536 & 76.5 \\
\hline & $\geq 80$ & 472 & 23.5 \\
\hline \multirow{3}{*}{ Vehicle Class } & Light Vehicle & 1750 & 87.2 \\
\hline & Heavy Vehicle & 182 & 9.1 \\
\hline & Others & 76 & 3.8 \\
\hline \multirow{2}{*}{ Rollover } & Yes & 265 & 13.2 \\
\hline & No & 1743 & 86.8 \\
\hline \multirow{3}{*}{ Seatbelt Use } & Yes & 1054 & 52.5 \\
\hline & No & 720 & 35.9 \\
\hline & Unknown & 210 & 10.5 \\
\hline \multirow{2}{*}{ Crash Severity } & Fatal & 101 & 5.0 \\
\hline & Not Fatal & 1907 & 95.0 \\
\hline
\end{tabular}

\subsection{Statistical Modeling}

Multivariate logistic regression models were used to:

(i) identify risk factors to fatal intersection crashes while controlling for potential crash severity contributing factors. These models aimed at addressing the first objective of this study (i.e., as stated in Section 1.2). In these models, crash-, road-, traffic-, intersection-, vehicle-, and driver-related factors were defined as independent variables, while crash severity was defined as the dependent or response variable.

(ii) quantify the odds of incurring fatal injuries given that collisions at different intersection types have occurred while also controlling for potential crash severity contributing factors. These models aimed at addressing the second objective of this study (i.e., as also stated in Section 1.2). In these models, intersection type was defined 
as the independent variable, while crash severity was defined as the dependent or response variable.

A univariate logit model may be mathematically expressed by Equation (1), where $x$ is the predictor variable (e.g., intersection type), $\pi(\mathrm{x})$ is the success (defined as fatal injury) probability at the value $x, \beta_{0}$ is the intercept, and $\beta$ represents the effect of the variable $x$ on the response variable.

$$
\text { Logit }[\pi(x)]=\beta_{0}+\beta x,
$$

A multivariate logit model with $n$ predictor variables may be expressed by Equation (2). In order to calculate the odds estimate, the exponential of the logit is determined by Equation (3). Since the response variable is binary (i.e., $y=$ non-fatal or fatal injury), a binary logit model was used. The binary logit model calculates the probability that the response, coded as y equal to 0 or 1 , is equal to 1 (e.g., $\pi$ [y $=$ fatal crash]), which would mean "success". Therefore, logistic regression models can help quantify the odds associated with a fatal crash occurrence upon a collision with different intersection types while controlling for a number of relevant vehicle-, road-, and occupant-related variables (i.e., potential crash severity contributing factors).

$$
\begin{gathered}
\operatorname{Logit}[\pi(x)]=\beta_{0}+\beta_{1} x_{1}+\beta_{2} x_{2}+\beta_{n} x_{n}, \\
\text { Odds }=e^{\left(\beta_{0}+\beta_{1} x_{1}+\beta_{2} x_{2}+\beta_{n} x_{n}\right)}
\end{gathered}
$$

In order to fit the logistic regression model, the coefficient(s) beta(s) need to be determined. The statistical method used to determine the model's parameters is the maximum likelihood estimation [69]. Hosmer and Lemeshow provide explanations on how the parameter values that maximize the likelihood function, in the case of a logistic regression model, are determined [70]. Iterative methods programmed into statistical software are used to solve likelihood equations using a generalized weighted least squares procedure [71] and find a value of $\beta$ that is the maximum likelihood estimate. All statistical analyses presented in this study were conducted using software Minitab 19 [72]. Model building procedures as well as goodness-of-fit test used during the development of the models contained in this study have been detailed in a recently published paper [73]. Therefore, interested readers are referred to this previously published paper, as the same procedures applied in that paper were applied to the current one.

\section{Results}

A total of 2008 intersection crashes were studied. These crashes occurred in the Emirate of Abu Dhabi between years 2012 and 2017. Out of these, $1214(60.45 \%)$ crashes occurred at signalized intersections, while $794(39.55 \%)$ crashes occurred at roundabouts. Seven percent of the roundabout crashes resulted in fatalities, while $3.7 \%$ of the signalized intersections resulted in fatalities.

Three different multivariate models were developed in this study. One multivariate model was developed to identify risk factors associated with fatal signalized intersection crashes (see Section 3.1), another multivariate model was developed to identify risk factors associated with fatal roundabout crashes (see Section 3.2), and one final multivariate model was developed to compare the in-service safety performances of signalized intersections to that of roundabouts (see Section 3.3).

\subsection{Risk Factors Associated with Fatal Signalized Intersection Crashes}

A univariate analysis was first performed using crash severity as the dependent variable and the other variables listed in Table 3 as the independent variables. Table 4 shows the results from the univariate analysis. Driver's age, distance between intersections, number of crash events, presence of the access points on the upstream intersection approach, presence of left-turn lanes, number of lanes in the intersection approach (i.e., where the vehicle at fault came from), vehicle class, number of intersection arms, number of vehicles 
involved, posted speed limit, and seatbelt usage were all considered in the multivariate analysis (i.e., based on a $p$-value of 0.25 or below). As mentioned in Section 2.2, details on why a $p$-value of 0.25 is used to consider variables further into a multivariate analysis can be found in a recently published study [73].

Table 4. Univariate Analysis: Signalized Intersections.

\begin{tabular}{|c|c|c|c|c|c|c|c|}
\hline Variable & $\begin{array}{l}\text { Non-Baseline } \\
\text { Category }\end{array}$ & $\begin{array}{l}\text { Baseline } \\
\text { Category }\end{array}$ & $\begin{array}{c}\text { Total \# } \\
\text { Observations }\end{array}$ & $\begin{array}{l}\text { \# Non-Baseline } \\
\text { Observations }\end{array}$ & Odds & $p$-Value & $\begin{array}{l}\text { ANOVA } \\
p \text {-Value }\end{array}$ \\
\hline Driver Age & - & - & 1208 & - & 0.98 & 0.25 & 0.25 \\
\hline $\begin{array}{c}\text { Distance Between } \\
\text { Signalized Intersections }\end{array}$ & $>500 \mathrm{~m}$ & $\leq 500 \mathrm{~m}$ & 1140 & 762 & 1.7 & 0.14 & 0.14 \\
\hline $\begin{array}{l}\text { Number of Crash } \\
\text { Events }\end{array}$ & Multiple & One & 1214 & 333 & 1.4 & 0.25 & 0.25 \\
\hline $\begin{array}{l}\text { Presence of Access } \\
\text { Points }\end{array}$ & No & Yes & 1179 & 182 & 1.6 & 0.20 & 0.20 \\
\hline $\begin{array}{l}\text { Presence of Separate } \\
\text { Left-Turn Lanes }\end{array}$ & $\begin{array}{l}\text { No lanes } \\
\text { Single Lane }\end{array}$ & Multiple Lanes & 1185 & $\begin{array}{l}151 \\
584\end{array}$ & $\begin{array}{l}1.1 \\
2.2\end{array}$ & $\begin{array}{l}0.9 \\
0.0\end{array}$ & 0.07 \\
\hline $\begin{array}{l}\text { Number of Intersection } \\
\text { Approach Lanes }\end{array}$ & $\leq 4$ & $\geq 5$ & 1179 & 577 & 1.6 & 0.13 & 0.13 \\
\hline Vehicle Class & Heavy Vehicle & Light Vehicle & 1174 & 87 & 2.4 & 0.05 & 0.05 \\
\hline $\begin{array}{l}\text { Number of Intersection } \\
\text { Arms }\end{array}$ & 3 & 4 & 1209 & 241 & 1.5 & 0.25 & 0.25 \\
\hline $\begin{array}{l}\text { Number of Vehicles } \\
\text { Involved }\end{array}$ & One & Multiple & 1214 & 166 & 3.61 & 0.00 & 0.00 \\
\hline $\begin{array}{l}\text { Posted Speed Limit } \\
\text { (kph) }\end{array}$ & $\geq 80$ & $\leq 60$ & 1214 & 263 & 1.61 & 0.14 & 0.14 \\
\hline Seatbelt Usage & No & Yes & 1004 & 385 & 4.41 & 0.00 & 0.00 \\
\hline
\end{tabular}

As can be seen, fatal injuries are 1.7 times more likely to occur (as compared to nonfatal injuries) at locations where intersections are separated by a distance of more than $500 \mathrm{~m}$ as compared to locations where intersections are separated by a distance shorter than $500 \mathrm{~m}$, though the $p$-value of 0.14 was marginally higher than the 0.10 commonly used for statistical significance purposes. In addition, presence of separate left-turn lanes, number of intersection approach lanes, vehicle class, number of vehicles involved, posted speed limit, and seatbelt usage all appeared to have a significant effect on the risk of fatality. However, a fairer analysis of the impact of diverse factors on crash severity would be performed using a multivariate model, as fatality risk would be investigated while multiple variables would be controlled for simultaneously. After applying the model building procedures described in [73], the model shown in Table 5 was found. Correlation analysis was carried out and it was observed no statistically significant correlation among variables included in the model building process.

The model contained in Table 5 indicates that the odds of fatal injury occurrence are: (i) 1.7 times more likely to occur at locations where intersections are separated by a distance of more than $500 \mathrm{~m}$ as compared to locations where intersections are separated by a distance shorter than $500 \mathrm{~m}$, (ii) higher at intersections with no or only a single left-turn lane than at intersections with multiple left-turn lanes, (iii) higher at intersections with longer left-turn lanes, (iv) higher when unbelted occupants are involved in a crash, (v) higher in multiple-event crashes (i.e., hitting roadside hazards, running over a human or bicycle, or rollover), and (vi) higher when there was no access point upstream intersection. 
Table 5. Multivariate Signalized Intersection Model.

\begin{tabular}{|c|c|c|c|c|c|c|c|c|}
\hline Variable & $\begin{array}{c}\text { Non-Baseline } \\
\text { Category }\end{array}$ & $\begin{array}{l}\text { Baseline } \\
\text { Category }\end{array}$ & $\begin{array}{c}\text { Total \# } \\
\text { Observations }\end{array}$ & $\begin{array}{l}\text { \# Non-Baseline } \\
\text { Observations }\end{array}$ & Odds & $p$-Value & $\begin{array}{l}\text { ANOVA } \\
p \text {-Value }\end{array}$ & $\begin{array}{c}\text { GOF } \\
(p \text {-Value })\end{array}$ \\
\hline $\begin{array}{l}\text { Distance Between } \\
\text { Signalized Intersections }\end{array}$ & $>500 \mathrm{~m}$ & $\leq 500 \mathrm{~m}$ & \multirow{6}{*}{940} & 620 & 1.7 & 0.19 & 0.19 & \multirow{6}{*}{0.66} \\
\hline Presence of Separate & $\begin{array}{l}\text { No Lanes } \\
\text { Single Lanes }\end{array}$ & Multiple & & $\begin{array}{l}117 \\
463\end{array}$ & $\begin{array}{l}2.6 \\
2.3\end{array}$ & $\begin{array}{l}0.17 \\
0.05\end{array}$ & 0.14 & \\
\hline $\begin{array}{l}\text { Left-Turn Lanes } \\
\text { Length of Left-Turn Lane }\end{array}$ & $\begin{array}{l}\text { Single Lanes } \\
\text { - }\end{array}$ & $\begin{array}{l}\text { Lanes } \\
\text { - }\end{array}$ & & $\begin{array}{c}463 \\
-\end{array}$ & $\begin{array}{l}2.3 \\
1.002\end{array}$ & $\begin{array}{l}0.05 \\
0.12\end{array}$ & 0.12 & \\
\hline Seatbelt Usage & No & Yes & & 365 & 6.2 & 0.00 & 0.00 & \\
\hline Number of Crash Events & Multiple & One & & 241 & 2.1 & 0.06 & 0.06 & \\
\hline Presence of Access Points & No & Yes & & 799 & 3.03 & 0.01 & 0.01 & \\
\hline
\end{tabular}

The variable "Distance Between Signalized Intersections" was broken down into ">500 $\mathrm{m}$ " and " $\leq 500 \mathrm{~m}$ ", which are thresholds different from those used for the variable "Distance Between Roundabout and Nearest Intersection" (see Table 3). The reason for this is that there would be a small sample for roundabouts with distance of $500 \mathrm{~m}$ or less (i.e., 78 out of 581). Likewise, only $15 \%$ of the crashes occurred on locations where intersections were separated by a distance larger than $1 \mathrm{~km}$ since the majority of the signalized intersection locations were urban areas.

The variable "Presence of Access Points" identifies whether there was an access point upstream the intersection or not. If the distance between intersections was $1 \mathrm{~km}$ or more, then the presence of access points was checked for only $1 \mathrm{~km}$ distance. However, if the distance between the intersections was shorter than $1 \mathrm{~km}$, then the presence of access points was checked for the entire distance between the intersections. Moreover, access point presence was identified for the intersection arm on which the driver at fault was driving [74].

Lastly, the Hosmer-Lemeshow, goodness-of-fit (GOF) test indicated that this model presented an acceptable fit based on a $p$-value of 0.66 , significantly higher than the critical value of 0.05 .

\subsection{Risk Factors Associated with Roundabout Crashes}

Table 6 shows the results from the univariate analysis conducted using the roundabout crash data only. Posted speed limit, approach curvature, distance between pedestrian crosswalk to the roundabout yielding line, roundabout island diameter, width of the entry approach, number of approach lanes, presence access points upstream roundabout approach, distance between roundabout and nearest intersection, rollover, lighting condition, vehicle class, number of vehicles involved, number of crash events, seatbelt usage, and driver's gender were all considered further into the multivariate analysis (i.e., based on a $p$-value of 0.25 or lower). After applying the model building procedures described in [73], the multivariate model shown in Table 7 was selected. Correlation analysis was carried out and it was observed no statistically significant correlation among variables included in the model building process.

As can be seen, the model shown in Table 7 indicates that the odds of fatal injury occurrence are higher: (i) as the width of the entry approach increases, (ii) as the roundabout island diameter increases, (iii) as rollovers occur, (iv) where there is no road lighting or where it was in poor condition, (v) in multiple-event crashes, (vi) when unbelted occupants were involved in a crash, and (vii) as driver at fault was female.

Finally, the goodness of fit of this model was also found to be adequate based on a $p$-value equal to 0.46 . 
Table 6. Univariate Analysis: Roundabouts.

\begin{tabular}{|c|c|c|c|c|c|c|c|}
\hline Variable & $\begin{array}{l}\text { Non-Baseline } \\
\text { Category }\end{array}$ & $\begin{array}{l}\text { Baseline } \\
\text { Category }\end{array}$ & $\begin{array}{c}\text { Total \# } \\
\text { Observations }\end{array}$ & $\begin{array}{l}\text { \# Non-Baseline } \\
\text { Observations }\end{array}$ & Odds & $p$-Value & $\begin{array}{l}\text { ANOVA } \\
p \text {-Value }\end{array}$ \\
\hline $\begin{array}{l}\text { Posted Speed Limit } \\
\text { (kph) }\end{array}$ & $\geq 80$ & $\leq 60$ & 794 & 209 & 1.39 & 0.25 & 0.265 \\
\hline Approach Curvature & - & - & 674 & - & 1.0015 & 0.25 & 0.25 \\
\hline $\begin{array}{l}\text { Distance Between } \\
\text { Pedestrian Crosswalk } \\
\text { and the Yielding Line }\end{array}$ & - & - & 235 & - & 1.0009 & 0.12 & 0.12 \\
\hline $\begin{array}{l}\text { Roundabout Island } \\
\text { Diameter }\end{array}$ & - & - & 794 & - & 1.0015 & 0.07 & 0.07 \\
\hline $\begin{array}{l}\text { Width of Entry } \\
\text { Approach }\end{array}$ & - & - & 682 & - & 1.13 & 0.05 & 0.05 \\
\hline $\begin{array}{l}\text { Number of Approach } \\
\text { Lanes }\end{array}$ & $\geq 3$ & $\leq 2$ & 681 & 366 & 1.6 & 0.12 & 0.12 \\
\hline $\begin{array}{l}\text { Presence of Access } \\
\text { Points }\end{array}$ & No & Yes & 683 & 239 & 1.46 & 0.18 & 0.18 \\
\hline $\begin{array}{l}\text { Distance Between } \\
\text { Roundabout and } \\
\text { Nearest Intersection }\end{array}$ & $>1 \mathrm{~km}$ & $\leq 1 \mathrm{~km}$ & 581 & 300 & 1.8 & 0.08 & 0.08 \\
\hline Rollover & Yes & No & 794 & 230 & 2.2 & 0.01 & 0.01 \\
\hline Lighting Condition & $\begin{array}{l}\text { Poor or no } \\
\text { Light }\end{array}$ & $\begin{array}{l}\text { Sufficient } \\
\text { Light }\end{array}$ & 794 & 43 & 2.3 & 0.07 & 0.07 \\
\hline Vehicle Class & Light Vehicle & $\begin{array}{l}\text { Heavy } \\
\text { Vehicle }\end{array}$ & 758 & 663 & 2.5 & 0.13 & 0.13 \\
\hline $\begin{array}{l}\text { Number of Vehicles } \\
\text { Involved }\end{array}$ & Single Vehicle & $\begin{array}{l}\text { Multiple } \\
\text { Vehicle }\end{array}$ & 794 & 566 & 1.9 & 0.08 & 0.08 \\
\hline $\begin{array}{l}\text { Number of Crash } \\
\text { Events }\end{array}$ & $\begin{array}{l}\text { Multiple } \\
\text { Events }\end{array}$ & Single Event & 794 & 422 & 3.82 & 0.00 & 0.00 \\
\hline Seatbelt Usage & No & Yes & 770 & 335 & 2.01 & 0.02 & 0.02 \\
\hline Gender & Female & Male & 787 & 66 & 1.66 & 0.23 & 0.23 \\
\hline
\end{tabular}

Table 7. Multivariate Roundabout Model.

\begin{tabular}{|c|c|c|c|c|c|c|c|c|}
\hline Variable & $\begin{array}{c}\text { Non-Baseline } \\
\text { Category }\end{array}$ & $\begin{array}{l}\text { Baseline } \\
\text { Category }\end{array}$ & $\begin{array}{c}\text { Total \# } \\
\text { Observations }\end{array}$ & $\begin{array}{l}\text { \# Non-Baseline } \\
\text { Observations }\end{array}$ & Odds & $p$-Value & $\begin{array}{l}\text { ANOVA } \\
p \text {-Value }\end{array}$ & $\begin{array}{c}\text { GOF } \\
(p \text {-Value) }\end{array}$ \\
\hline $\begin{array}{l}\text { Width of Entry } \\
\text { Approach }\end{array}$ & - & - & \multirow{7}{*}{654} & - & 1.2 & 0.06 & 0.06 & \multirow{7}{*}{0.46} \\
\hline $\begin{array}{c}\text { Roundabout Island } \\
\text { Diameter }\end{array}$ & - & - & & - & 1.0021 & 0.07 & 0.07 & \\
\hline Rollover & Yes & No & & 188 & 1.9 & 0.05 & 0.05 & \\
\hline Lighting Condition & $\begin{array}{l}\text { Poor or No } \\
\text { Light }\end{array}$ & $\begin{array}{c}\text { Sufficient } \\
\text { Light }\end{array}$ & & 34 & 3.2 & 0.02 & 0.02 & \\
\hline $\begin{array}{c}\text { Number of Crash } \\
\text { Events }\end{array}$ & $\begin{array}{l}\text { Multiple } \\
\text { Events }\end{array}$ & $\begin{array}{l}\text { Single } \\
\text { Event }\end{array}$ & & 360 & 3.9 & 0.00 & 0.00 & \\
\hline Seatbelt Usage & No & Yes & & 304 & 2.0 & 0.03 & 0.03 & \\
\hline Gender & Female & Male & & 54 & 2.5 & 0.04 & 0.04 & \\
\hline
\end{tabular}

\subsection{In-Service Safety Performance Evaluation: Signalized Intersections versus Roundabouts}

The model presented in this section intends to address the second objective of this study (see Section 1.2): to compare the in-service safety performance of signalized intersections and roundabouts. In this analysis, crash severity was set as the dependent variable, while intersection type was defined as an independent variable. After applying the model building procedures described in [73], the multivariate model shown in Table 8 was selected. Correlation analysis was carried out and it was observed no statistically significant correlation among variables included in the model building process.

As can be seen, the model shown in Table 8 indicates that the odds of fatal injury occurrence are 1.8 times higher for signalized intersection crashes than those for roundabout crashes while controlling for the presence of access points, lighting condition, object struck, and seatbelt usage. 
Table 8. Multivariate Roundabout Model.

\begin{tabular}{|c|c|c|c|c|c|c|c|c|}
\hline Variable & $\begin{array}{l}\text { Non-Baseline } \\
\text { Category }\end{array}$ & $\begin{array}{l}\text { Baseline } \\
\text { Category }\end{array}$ & $\begin{array}{c}\text { Total \# } \\
\text { Observations }\end{array}$ & $\begin{array}{l}\text { \# Non-Baseline } \\
\text { Observations }\end{array}$ & Odds & $p$-Value & $\begin{array}{l}\text { ANOVA } \\
p \text {-Value }\end{array}$ & $\begin{array}{c}\text { GOF } \\
(p \text {-Value })\end{array}$ \\
\hline Intersection Type & Signal & Roundabout & \multirow{5}{*}{1462} & 607 & 1.8 & 0.12 & 0.12 & \multirow{5}{*}{0.51} \\
\hline $\begin{array}{c}\text { Presence of Access } \\
\text { Points }\end{array}$ & No & Yes & & 370 & 1.9 & 0.02 & 0.02 & \\
\hline Lighting Condition & $\begin{array}{c}\text { Poor or No } \\
\text { Light }\end{array}$ & $\begin{array}{l}\text { Sufficient } \\
\text { Light }\end{array}$ & & 40 & 2.2 & 0.12 & 0.12 & \\
\hline Object Struck & $\begin{array}{l}\text { None } \\
\text { Roadside } \\
\text { Hazard }\end{array}$ & Vehicle & & $\begin{array}{c}45 \\
427\end{array}$ & $\begin{array}{l}0.5 \\
1.9\end{array}$ & $\begin{array}{l}0.50 \\
0.07\end{array}$ & 0.09 & \\
\hline Seatbelt Usage & No & Yes & & 524 & 2.3 & 0.00 & 0.00 & \\
\hline
\end{tabular}

\section{Discussions and Conclusions}

The present study analyzed 2008 intersection-injury crashes that occurred in the Emirate of Abu Dhabi between 2012 and 2017. Results from this study indicate that the risk of fatalities increased as:

(i) signalized intersections are separated by longer distances and have no access point upstream, which may be explained by the fact that these characteristics may be associated with roads with higher posted speed limits and, therefore, may result in crashes involving faster traveling vehicles. Previous research has shown that adding merging lanes for inbound vehicles, near intersections, can improve road safety [75]. These merging lanes have the potential to reduce interactions among inbound and merging vehicles;

(ii) signalized intersections had no or only one left-turn lane, which may be explained by the fact that intersections with no or only one left-turn lane may involve permitted rather than protected left-turning movements. That is, intersections with no or only one-left turn lane were located on 2-lane roads carrying lower traffic volumes and, therefore, left-turning movements were not protected. This confirms findings from previous studies [76,77];

(iii) signalized intersections contained longer left-turn lanes, which may be explained by the fact that longer left-turn lanes were more likely to be present at intersections with larger to left-turning traffic, increasing the chance of crashes involving more severe impact conditions (e.g., near head-on impacts);

(iv) signalized intersection or roundabout crashes involved more than one event such as multiple-event crashes involving vehicles running off the road, hitting curbs, and other roadside hazards located in the median;

(v) signalized intersection or roundabout crashes involved unbelted vehicle occupants. In fact, crashes involving unbelted occupants were over six times more likely to result in fatalities as compared to crashes not involving unbelted occupants. This provides evidence for the case to strive for absolute compliance to seatbelt usage in order to improve safety;

(vi) roundabouts have wider entry approaches and larger center islands. This may be explained by the fact that roundabouts with these characteristics allow for faster traveling speeds;

(vii) roundabouts have no or poor lighting. It was often described in the crash description fields that the occurrence of roundabout crashes were often influenced by the driver's inability to see the roundabout. This finding highlights the importance of proper signage and/or lighting at roundabout locations;

(viii) roundabout crashes involved rollovers. Many of these rollover events occurred after vehicles hit curbs. Previous studies showed that a significant portion of the roadside design adopted in the Emirate of Abu Dhabi is non-compliant to state-ofthe-art guidelines largely due to excessively high curbs [78], which may likely have contributed to vehicle instability, eventually resulting in rollovers; and

(ix) crashes occurred at signalized intersections rather than at roundabouts. Indeed, the odds of fatal injury occurrence was found to be 1.8 times higher at signalized 
intersections as compared to roundabouts while controlling for the presence of access points, lighting condition, object struck, and seatbelt usage, though this finding is based on a $p$-value marginally higher than the widely used 0.10 threshold.

In sum, the findings from the present study provide road designers with input on factors that contribute to fatal signalized intersection and roundabout crashes, as well as decision-makers with much needed locally-produced scientific evidence, that converting existing roundabouts into signalized intersections actually deteriorates road safety, increasing the fatality risk of the motoring public in the UAE. It is important to note, however, that there may be other factors influencing intersection safety that might not have been captured by the data used in the statistical modeling adopted in this study. As such, road safety audits/inspections may be undertaken as an attempt to collect data on control variables that were missing in the database (and therefore not included in this study), but that still might affect safety [79]. Nonetheless, the findings of this research should also benefit neighboring GCC countries considering their similarities in road design, traffic characteristics, and driving culture.

\section{Recommendations}

The significant amount of evidence available in the literature, as well as the findings from this study, back the idea that there are safety benefits associated with the conversion of signalized intersections to roundabouts. It is important to stress that the present study indicated that there are safety benefits to be reaped from roundabout adoption even though operating speeds prevailing on Abu Dhabi's roundabouts may be too high [68]. These excessively high operating speeds may be attributed to both reckless driving behavior [67] as well as large roundabout diameters. In Abu Dhabi, roundabouts usually have multiple lanes, resulting in large diameters. In fact, the median diameter of the roundabouts included in this present study was found to be $61 \mathrm{~m}$. Such wide diameters augment the tendency for higher operating speeds. A such, these large Abu Dhabi roundabouts might not have produced the safety benefits that they could have had were they smaller.

Recent research has proposed some design modifications to the traditional roundabouts as a means to improve safety. That is, turbo roundabouts have been proposed as a mean to decrease conflict points associated with merging/exiting or lane-changing movements [80]. Indeed, research has shown that turbo roundabouts produce safety benefits in relation to traditional roundabouts [81-84]. Features such as lane dividers and spiral road markings may have contributed to improved safety associated with turbo roundabouts $[85,86]$.

Thus, based on past research findings and research findings from the present study, it is recommended that roundabouts be preferred due to their safety benefits. As mentioned previously, more recent research has suggested that these safety benefits may even be increased if turbo roundabouts are used $[82,83]$. However, given that roundabouts may be replaced by signalized intersections due to operational reasons (i.e., to decrease intersection delay/congestion during certain times), the authors recommend road design and decisionmakers to ask the following questions before giving the go-ahead to projects which may primarily be concerned with increased car-mobility levels at intersections, especially during peak hours:

(i) In the case of new projects: are the economic benefits associated with decreased delay being traded-off against an increase in the risk of injury or death?

(ii) In the case of retrofitting projects (i.e., in the form of a roundabout replacement by a signalized intersection), can the economic benefits associated with decreased peak delay offset an increase in the risk of injury or death plus the design/construction/maintenance cost associated with traffic signal operation?, and

(iii) Is net daily delay associated with the adoption of a signalized intersection decreased or increased? Here, net daily delay is defined as the delay reduced during the peak hour plus the delay increased during off-peak hours due to red-light-waiting times. 
Author Contributions: Conceptualization, F.D.B.d.A.; methodology, F.D.B.d.A. and D.M.M.A.; software, D.M.M.A.; formal analysis, F.D.B.d.A. and D.M.M.A.; investigation, D.M.M.A.; writing-original draft preparation, F.D.B.d.A.; writing-review and editing, D.M.M.A.; visualization, D.M.M.A.; supervision, F.D.B.d.A.; project administration, F.D.B.d.A.; funding acquisition, F.D.B.d.A. Both authors have read and agreed to the published version of the manuscript.

Funding: This research was funded by United Arab Emirates University, grant number 31R202.

Institutional Review Board Statement: Ethical review and approval were waived for this study as anonymous crash data was provided by Abu Dhabi Traffic Police.

Informed Consent Statement: Informed consent was not needed as participants cannot be identified.

Data Availability Statement: Data is not publicly available. Data was obtained from Abu Dhabi Traffic Police.

Acknowledgments: The authors would like to thank the United Arab Emirates University for funding this research effort under grant number 31R202. The authors would also like to thank the staff at the Abu Dhabi Traffic Police for the provision of the crash data needed for this study, as well as for their assistance.

Conflicts of Interest: The authors declare no conflict of interest. The funders had no role in the design of the study; in the collection, analyses, or interpretation of data; in the writing of the manuscript, or in the decision to publish the results.

\section{References}

1. Al Kuttab, J.; Abdullah, A. Two People Die on UAE Roads Every Day. Available online: https://www.khaleejtimes.com/nation/ two-people-die-every-day-on-uae-roads (accessed on 3 May 2021).

2. Shahbandari, S. Road Crashes Cost Dubai Dh1.8b A Year. Available online: https://gulfnews.com/news/uae/road-crashes-costdubai-dh1-8b-a-year-1.1470277 (accessed on 15 May 2021).

3. Al Ramahi, N. Dubai Police: 525 Road Traffic Deaths in 2017. Available online: https://www.thenational.ae/uae/dubai-police525-road-traffic-deaths-in-2017-1.691319 (accessed on 15 May 2021).

4. Rohrer, W.M. Road Traffic Accidents as Public Health Challenge in the Gulf Cooperation Council (GCC) Region. Open Public Health J. 2016, 1, e6-e7. [CrossRef]

5. Toumi, H. One Traffic Accident Per Minute in Saudi Arabia. Gulf News Saudi Arabia. Available online: https://gulfnews.com/ news/gulf/saudi-arabia/one-traffic-accident-per-minute-in-saudi-arabia-1.2129414 (accessed on 25 May 2021).

6. Ansari, S.; Akhdar, F.; Mandoorah, M.; Moutaery, K. Causes and Effects of Road Traffic Accidents in Saudi Arabia. Public Health 2000, 114, 37-39. [CrossRef]

7. Scott, V. Study: Traffic Accidents Cost Qatar Nearly \$5 Billion over Six Years. Available online: https://dohanews.co/studycounts-huge-cost-road-accidents-qatar/ (accessed on 25 May 2021).

8. Al Shaibany, S. Oman Begins Traffic Safety Campaign as Road Deaths Rise. Available online: https://www.thenationalnews. com/world/oman-begins-traffic-safety-campaign-as-road-deaths-rise-1.75680 (accessed on 25 May 2021).

9. Toumi, H.A. Car Accident Every 10 Minutes in Kuwait. Available online: https://gulfnews.com/news/gulf/kuwait/a-caraccident-every-10-minutes-in-kuwait-1.2065034 (accessed on 25 May 2021).

10. Albuquerque, F.D.B. The Running-Red-Light Problem in Abu Dhabi; Unpublished Presentation: Abu Dhabi, United Arab Emirates, 2015.

11. Federal Highway Administration (FHWA). About Intersection Safety. Available online: https://safety.fhwa.dot.gov/intersection/ about/ (accessed on 27 May 2021).

12. The World Health Organization (WHO). Global Plan for the Decade of Action for Road Safety 2011-2020; WHO: Geneva, Switzerland, 2011.

13. Lalani, N. The impact on accidents of the introduction of mini: Small and large roundabouts at major/minor priority junctions. Traffic Eng. Control 1975, 16, 560-561.

14. Green, H. Accidents at Off-Side Priority Roundabouts with Mini or Small Islands; TRRL Laboratory Report 774; Transport and Road Research Laboratory: Crowthorne, Berkshire, UK, 1977.

15. Lahrmann, H. Rundkørsler: Trafiksikkerhed, Geometrisk Udformning, Kapacitet, 2nd ed.; Vejdirektoratet, Sekretariatet for Sikkerhedsfremmende Vejforanstaltninger (SSV): Næstved, Denmark, 1981.

16. Cedersund, H.-Å. Cirkulationsplatser; VTI-Meddelande 361; Statens Väg-och Trafikinstitut (VTI): Linköping, Sweden, 1983.

17. Cedersund, H.-Å. Olyckor I Tätortskorsningar; VTI-meddelande 362; Statens Väg-och Trafikinstitut (VTI): Linköping, Sweden, 1983.

18. Senneset, G. Rundkjøringer. Del II Hovedrapport. Erfaringer fra utvalgte rundkjøringer i Norge; STF63 A83001 II; SINTEF Samferdselsteknikk: Trondheim, Norway, 1983. 
19. Brüde, U.; Larsson, J. Korsningsåtgärder Vidtagna Inom Vägförvaltningarnas Trafiksäkerhetsarbete. Regressions och åtgärdseffekter; VTI-rapport 292; Statens Väg-och Trafikinstitut (VTI): Linköping, Sweden, 1985.

20. Johannessen, S. Rundkjøringer. In Forslag til Retningslinjer Basert på Data om 35 Rundkjøringer; STF63 A85008; SINTEF Samferdselsteknikk: Trondheim, Norway, 1985.

21. Hall, R.D.; McDonald, M. Junction design for safety. In Roads and Traffic 2000, Proceedings of the International Road and Traffic Conference, Berlin, Germany, 6-9 September 1988; Road and Transportation Research Assoc.: Germany, 1988; pp. $147-151$.

22. Nygaard, H.C. Erfaringer Med Rundkjøringer i Akershus; Statens Vegvesen Akershus: Oslo, Norway, 1988.

23. Corben, B.; Ambrose, C.; Wai, F.C. Evaluation of Accident Black Spot Treatments Report 11; Monash University: Melbourne, Australia, 1990.

24. Giæver, T. Ulykkesfrekvenser i Rundkjøringer og Signalregulerte Kryss; STF63 A90002; SINTEF Samferdselsteknikk: Trondheim, Norway, 1990.

25. Tudge, R.T. Accidents at roundabouts in new south wales. In Australian Road Research Board, Proceedings of the 15th ARRB Conference, Darwin, Northern Territory, 26-31 August 1990; Melbourne, Australia, 1990; Part 5; pp. 331-349. Available online: https: / / library.swov.nl/action/ front/cardweb?id=83864 (accessed on 29 July 2021).

26. Van Minnen, J. Ongevallen op rotondes. In Vergelijkende Studie van de Onveiligheid op een Aantal Locaties Waar een Kruispunt Werd Vervangen Door een Nieuwe Rotonde; R-90-47; Stichting Wetenschappelijk Onderzoek Verkeersveiligheid (SWOV): Leidschendam, The Netherlands, 1990.

27. Jørgensen, N.O. Rundkørslers kapacitet og sikkerhed. In Dokumentasjonsrapport. Danmarks Tekniske Højskole; Institut for Veje, Trafik og Byplan: København, Denmark, 1991.

28. Brüde, U.; Larsson, J. Trafiksäkerhet $i$ tätortskorsningar VTI-meddelande 685; Statens Väg-och Trafikinstitut (VTI): Linköping, Sweden, 1992.

29. Brabander, B.D.; Vereeck, L. Safety effects of roundabouts in Flanders: Signal type, speed limits and vulnerable road users. Accid. Anal. Prev. 2007, 39, 591-599. [CrossRef]

30. Dagersten, A. Roundabouts in Switzerland and Sweden; Lund Institute of Technology, Department of Traffic Planning and Engineering: Lund, Sweden, 1992.

31. Holzwarth, J. Ausserorts-Kreisverkehrsplätze zur Unfallstellenbeseitigung-Ergebnisse zweier Modellvorhaben in BadenWürttemberg. Strassensverkehrstechnik 1992, 36, 142-146.

32. Hydén, C.; Odelid, K.; Várhelyi, A. Effekten av generell hastighetsdämpning i tätort. Resultat av et storskaligt försök i Växjö. I. In Huvudrapport. Lunds Tekniske Høgskola; Institutionen för Trafikteknik: Lund, Sweden, 1992.

33. Jørgensen, E.; Jørgensen, N.O. Er der mere nyt om rundkørsler? Dansk Vejtidsskrift 1992, 12, $29-31$.

34. Kristiansen, P. Erfaringer med rundkjøringer i Akershus; Statens Vegvesen Akershus: Oslo, Norway, 1993.

35. Schnüll, R.; Haller, W.; Von Lübke, H. Sicherheitsanliegen bei der Umgestaltung von Knotenpunkten in Städten. Forschungsberichte der Bundesanstalt für Strassenwesen (BASt) 253; Bundesanstalt für Strassenwesen: Bergisch-Gladbach, Germany, 1992.

36. Værø, H. Effekt af sortpletbekæmpelse i Hillerød; Vejdirektoratet, Trafiksikkerhedsafdelingen: København, Denmark, 1992.

37. Værø, H. Effekt af sortpletbekæmpelse i Nyborg; Vejdirektoratet, Trafiksikkerhedsafdelingen: København, Denmark, 1992.

38. Værø, H. Effekt af sortpletbekæmpelse i Silkeborg; Vejdirektoratet, Trafiksikkerhedsafdelingen: København, Denmark, 1992.

39. Værø, H. Effekt af sortpletbekæmpelse i Skælskør; Vejdirektoratet, Trafiksikkerhedsafdelingen: København, Denmark, 1992.

40. Brilon, W.; Stuwe, B.; Drews, O. Sicherheit und Leistungsfähigkeit von Kreisverkehrsplätzen FE Nr 77359/91. In Lehrstuhl für Verkehrswesen; Ruhr-Universität: Bochum, Germany, 1993.

41. Schoon, C.C.; Van Minnen, J. Ongevallen op Rotondes II. In Tweede Onderzoek naar de Onveiligheid van Rotondes vooral voor Fietsers en Bromfietsers; R-93-16; SWOV Institute for Road Safety Research: Leidschendam, The Netherlands, 1993.

42. Voss, H. Zur Verkehrssicherheit innenörtlicher Knotenpunkte. Zeitschrift für Verkehrssicherheit 1994, 40, 68-72.

43. Jørgensen, E.; Jørgensen, N.O. Sikkerhed i nyere danske rundkørsler. In Proceedings of the Paper Presentert Ved Trafikdage Ved Aalborg Universitets Center (AUC), Aalborg, Denmark, 28-30 August 1994; Institut for Samfundsudvikling og Planlægning, Aalborg Universitet: Aalborg, Denmark; pp. 191-198.

44. Seim, R. Analyse av kryssulykker i Akershus fylke 1990-93. In Hovedoppgave i Samferdselsteknikk Høsten 1994; Norges Tekniske Høgskole, Institutt for samferdselsteknikk: Trondheim, Norway, 1994.

45. Huber, C.A.; Bühlmann, F. Sicherheit von Kreiselanlagen. Erfahrungen und vorläufige Empfehlungen. In Pilotstudie; Schweitzerische Beratungsstelle für Unfallverhütung: Bern, Switzerland, 1994.

46. Bureau of Transport and Communication Economics. Evaluation of the Black Spot Program; Report 90; Bureau of Transport and Communication Economics (BTCE): Canberra, Australia, 1995.

47. Oslo Veivesen. Ulykkesanalyse. In Rundkjøringer i Oslo; Statens Vegvesen: Oslo, Norway, 1995.

48. Flannery, A.; Datta, T.K. Modern roundabouts and traffic crash experience in the United States. In Proceedings of the Transportation Research Board 75th Annual Meeting, Washington, DC, USA, 7-11 January 1996; p. 960658.

49. Odberg, T.A. Erfaringer med rundkjøringer i Vestfold. In Hovedoppgave i Samferdselsteknikk; Norges Teknisk-Naturvitenskapelige Universitet, Institutt for samferdselsteknikk: Trondheim, Norway, 1996.

50. Giæver, T. Rundkjøringer i Hordaland_Ulykkesanalyser, Utforming og Trafikantatferd; Rapport STF22 A97601; Samferdsel: Trondheim, Norway, 1997; SINTEF Bygg og miljøteknikk. 
51. Flannery, A.; Elefteriadou, L.; Koza, P.; McFadden, J. Safety, delay, and capacity of single-lane roundabouts in the United Stated. Transp. Res. Rec. 1998, 1646, 63-70. [CrossRef]

52. Mountain, L.; Maher, M.; Fawaz, B. Improved estimates of the safety effects of accident remedial schemes. Traffic Eng. Control $1998,10,554$.

53. Newstead, S.; Corben, B. Evaluation of the 1992-1996 Transport Accident Commission Funded Accident Black Spot Treatment Program in Victoria; Report No. 182; Monash University Accident Research Centre: Melbourne, Australia, 2001.

54. Persaud, B.N.; Retting, R.A.; Gårder, P.E.; Lord, D. Observational Before-after Study of the Safety Effect of US Roundabout Conversions Using the Empirical Bayes Method; TRB Paper 01-0562; Transportation Research Board: Washington, DC, USA, 2001.

55. Meuleners, L.; Hendrie, D.; Lee, A.H.; Legge, M. Effectiveness of the black spot programs in western Australia. Accid. Anal. Prev. 2008, 40, 1211-1216. [CrossRef] [PubMed]

56. Schelling, A.; Jespersen, L.K. Sorte pletter på statsveje. In Evaluering 2009; Vejdirektoratet: København, Denmark, 2009.

57. Gross, F.; Lyon, C.; Persaud, B.; Srinivasan, R. Safety effectiveness of converting signalized intersections to roundabouts. Accid. Anal. Prev. 2013, 50, 234-241. [CrossRef]

58. Underlien Jensen, S. Safety effects of converting intersections to roundabouts. Transp. Res. Rec. 2013, 2389, 22-29. [CrossRef]

59. De Pauw, E.; Daniels, S.; Brijs, T.; Hermans, E.; Wets, G. Safety effects of an extensive black spot treatment programme in Flanders-Belgium. Accid. Anal. Prev. 2014, 66, 72-79. [CrossRef] [PubMed]

60. Hu, W.; McCartt, A.T.; Jermakian, J.S.; Mandavilli, S. Public opinion traffic performance, the environment, and safety after construction of double-lane roundabouts. Transp. Res. Rec. 2014, 2402, 47-55. [CrossRef]

61. Rousseau, O. Abu Dhabi's Musanada Launches \$119m Al Ain Roadworks. Available online: https:/ / www.constructionweekonline. com/article-50615-abu-dhabis-musanada-launches-119m-al-ain-roadworks (accessed on 11 February 2019).

62. Wam. Works Begin on Dhs183m Roundabout Development Project in Al Ain City. Available online: https://www.emirates247 .com/business/works-begin-on-dh183m-roundabout-development-in-al-ain-2019-08-18-1.688544 (accessed on 25 February 2020).

63. Elvik, R. Effects on road safety of converting intersections to roundabouts-Review of evidence from non-US studies. Transp. Res. Rec. 2003, 1897, 200-205. [CrossRef]

64. Hauer, E. Observational Before-After Studies in Road Safety; Emerald Group Publishing Limited: Bingley, UK, 1997.

65. Elvik, R. Road Safety Effects of Roundabouts: A Meta-Analysis. Accid. Anal. Prev. 2017, 99, 364-371. [CrossRef]

66. Guin, A.; Rodgers, M.O.; Gbologah, T. Safety Evaluation of Roundabouts in Georgia; Publication FHWA-GA-18-1507; Georgia Tech Research Corp.: Atlanta, GA, USA, 2018.

67. Albuquerque, F.D.B.; Awadalla, D.M. Characterization of Road Crashes in the Emirate of Abu Dhabi. Transp. Res. Procedia 2020, 48, 1095-1110. [CrossRef]

68. Dabbour, E.; Al Awadhi, M.; Aljarah, M.; Mansoura, M.; Haider, M. Evaluating Safety Effectiveness of Roundabouts in Abu Dhabi. IATSS Res. 2018, 42, 274-283. [CrossRef]

69. Eliason, S.R. Quantitative Applications in the Social Sciences. Maximum Likelihood Estimation: Logic and Practice, 1st ed.; SAGE Publications Inc.: Newbury Park, CA, USA, 1993; Volume 96.

70. Hosmer, D.; Lemeshow, S. Applied Logistic Regression, 2nd ed.; Wiley Interscience Publication: New York, NY, USA, 2000.

71. McCullagh, P.; Nelder, J.A. Chapman \& Hall/CRC Monographs on Statistics and Applied Probability. In Generalized Linear Models, 2nd ed.; Chapman and Hall/CRC: London, UK, 1989.

72. Ryan, B.F.; Ryan, T.A.; Joiner, B.L. Minitab 19; Minitab LLC: State College, PA, USA, 2019.

73. Albuquerque, F.D.B.; Awadalla, D.M. Roadside Fixed-Object Collisions, Barrier Performance, and Fatal Injuries in Single-Vehicle, Run-Off-Road Crashes. Safety 2020, 6, 27. [CrossRef]

74. Government of Abu Dhabi. Access Management Policy and Procedures, 1st ed.; Department of Municipal Affair and Transport: Abu Dhabi, United Arab Emirates, 2016.

75. Gluck, J.; Levinson, H.S.; Stover, V. Impacts of Access Management Techniques; Transportation Research Board: Washington, DC, USA, 1999.

76. Naik, B. Offsetting Opposing Left-Turn Lanes at Signalized Intersections: A Safety Assessment Case Study in Lincoln, Nebraska. In Proceedings of the The Midwest Transportation Consortium Student Conference; 2005. Available online: https: / / www.semanticscholar.org/paper/Offsetting-Opposing-Left-Turn-Lanes-at-Signalized-A-Naik/60e2deee8bfd337 8afdf618dec3e685c446e010a\#citing-papers (accessed on 29 July 2021).

77. Harwood, D.W.; Bauer, K.M.; Potts, I.B.; Torbic, D.J.; Richard, K.R.; Rabbani, E.R.K.; Hauer, E.; Elefteriadou, L. Safety Effectiveness of Intersection Left and Right-Turn Lanes; Publication FHWA-RD-02-089; FHWA/Office of Safety Research and Development: McLean, VA, USA, 2002.

78. Awadalla, D.M.; Albuquerque, F.D.B. Impact of Roadside Design Compliance and Hazard Offset on the Risk of Single-Vehicle, Run-Off-Road Crash Fatalities. Int. J. Inj. Control. Saf. Promot. 2021, 1-11. [CrossRef]

79. Elvik, R.; Hoye, A.; Vaa, T.; Sorensen, M. The Handbook of Road Safety Measures, 2nd ed.; Emeral Group Publishing Limited: Bingley, UK, 2009.

80. Fortuijn, L.G.H. Turbo roundabouts: Design Principles and Safety Performance. Transp. Res. Rec. J. Transp. Res. Board 2009, 2096, 16-24. [CrossRef] 
81. Murphy, T. The Turbo Roundabout: A First in North America. In Proceedings of the 2015 Conference of the Transportation Association of Canada, Charlottetown, PE, Canada, 27-30 September 2015; Transportation Association of Canada: Charlottetown, PE, Canada; pp. 27-30.

82. Gallelli, V.; Perri, G.; Vaiana, R. Operational and Safety Management at Intersections: Can the Turbo-Roundabout Be an Effective Alternative to Conventional Solutions? Sustainability 2021, 13, 5103. [CrossRef]

83. Tollazzi, T.; Turnšek, S.; Renčelj, M. Slovenian experiences with turbo-Roundabouts. In Proceedings of the 3rd International Book on Roundabouts, TRB, Carmel, IN, USA, 3 June 2011.

84. Tollazzi, T.; Renčelj, M. Turbo-roundabouts in Slovenia-State of the art. In Proceedings of the XII International Symposium "Road Accidents Prevention 2014", Borsko Jezero, Serbia, 9-10 October 2014.

85. Džambas, T.; Ahac, S.; Dragčević, V. Geometric design of turbo roundabouts. Teh. Vjesn. Tech. Gaz. 2017, 24, 309-318.

86. Guerrieri, M.; Mauro, R.; Parla, G.; Tollazzi, T. Analysis of kinematic parameters and driver behavior at turbo roundabouts. J. Transp. Eng. Part A Syst. 2018, 144, 04018020. [CrossRef] 